\title{
Microstructural Characterization and Deformation of X10CrAISi24 Sheet Material Applied V-Bending Process
}

\author{
Mustafa ÖZDEMIR, Hakan GÖKMEŞE
}

\begin{abstract}
This study used X10CrAlSi24 (1.4762) sheet material, which is widespread in bending processes of the energy sector. During bending of X10CrAlSi24 (1.4762) sheet materials, cracking and tearing occur due to these materials' brittleness at room temperatures. To avoid this phenomenon, bending was carried out by applying normalization treatments at $800{ }^{\circ} \mathrm{C}, 850^{\circ} \mathrm{C}, 900{ }^{\circ} \mathrm{C}$ and $950{ }^{\circ} \mathrm{C}$. V-bending processes were performed at three different bending angles $\left(30^{\circ}, 60^{\circ}, 90^{\circ}\right)$ and by a $4.5 \mathrm{~mm}$ punch tip radius. V-bending processes were carried out without leaving the punch on the material, and crushing of the punch on the sheet material sectional area was allowed. As a result of the bending processes, spring-go occurred in the $30^{\circ}$ and $60^{\circ}$ bending applications, whereas spring-back occurred in the $90^{\circ}$ bending applications. The formation mechanism of capillary cracks (depending on deformation) due to internal stress especially at low temperatures was introduced by the microstructural characterization of the specimens.
\end{abstract}

Keywords: bending; heat treatment; spring-back; spring-go; sheet metal forming

\section{INTRODUCTION}

Spring-back and spring-go are two of the most common problems in sheet metal forming operations. In the bending process, the elasticity limit of specimens is exceeded, but the yield stresses are not exceeded. For this reason, the material maintains a part of its original flexibility. The material exhibits some spring-back or spring-go when the exerted load is removed. Spring-back is defined as reduction of bending angle after the bending process (Fig. 1a) while spring-go is increase of bending angle obtained as a result of bending (Fig. 1b). In the sheet material industry, especially in sheet bending processes, spring-back and spring-go have a significant effect. In the manufacturing industry, die designers and manufacturers try to find a die angle either by calculation or trial. As it is known, these methods cause both a waste of time and increasing costs. The spring-back and -go amounts are determined. According to the type of the bending material, this determination provides suitable die design and manufacturing by subtracting or adding values (obtained during die manufacturing) upon the bending angle. This process decreases the material waste and allows re-gaining the time that is lost with the method of trial and error [2]. Bending processes have an important place in the manufacturing industry. Owing to several bending applications, materials can be prepared in the desired accuracy of size and dimension [3]. Among bending applications, the most preferable one is the $\mathrm{V}$ bending method.

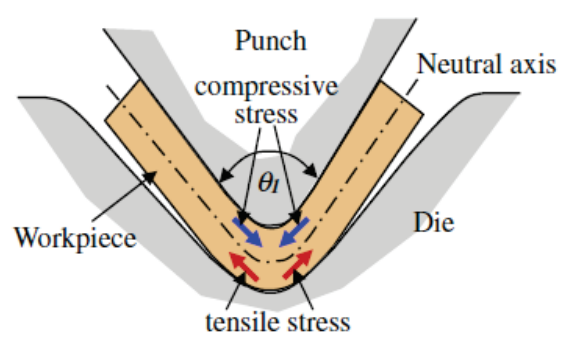

(a) Before removing the punch and die

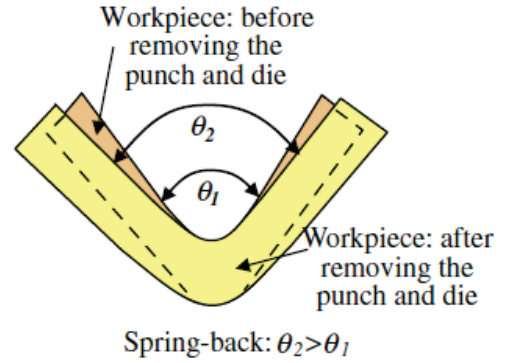

(b) After removing the punch and die

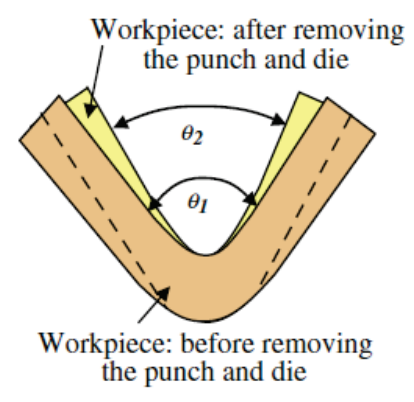

(c) Spring-go: $\theta_{2}<\theta_{l}$

Figure 1 Determination of spring-back and spring-go [1]

Steel sheets, copper and stainless-steel materials can easily be bent. During bending processes, it is seen that waiting time and material thicknesses are effective on spring-back [4-6]. The effect of material thickness on bending processes was reported in previous studies [7]. Studies are also increasing on the spring-back and -go amounts in $\mathrm{V}$ bending processes [8-11]. It is also known that there are significant improvements decreasing the amount of spring-back. Besides, elasticity modulus, friction condition and material properties are also effective on the amounts of spring-back [12-14]. In addition to this, in the processes of $\mathrm{V}$ bending, an important point is the spring-go amount and studies to decrease spring-go amounts are becoming more prevalent $[15,16]$. The effects of process parameters such as bending angle, material thickness, material properties and punch radius on $\mathrm{V}$-bending processes were analysed with the Taguchi and finite element methods, and suitable bending conditions were taken into consideration [17-20]. Formability and spring-back characterization of TRIP800 steel are investigated by finite element analysis method using different material models like Hill-48, Barlat-89 and YLD2000. Additionally, the capability of the Hill-48 and Barlat-89 models to predict the variation of the yield stress and anisotropy values were investigated by different methods like Lankford parameters and ErrMin 
approaches [21]. In $\mathrm{U}$ and $\mathrm{V}$ bending processes the sheet material was cut in angles of $0^{\circ}, 45^{\circ}$ and $90^{\circ}$ throughout the rolling direction and the obtained spring-back and -go amounts were examined after the bending process [22]. In $\mathrm{U}$ and $\mathrm{V}$ bending processes, the effect of sheet thickness, sheet anisotropy, material properties, coefficient of friction, punch tip and size on spring-back/go was also considered by researchers [23]. Accurately measuring the spring-back amounts in three distinct tooling regions (i.e., die corner, punch corner and side wall) were explained in detail under a wide range of operating conditions. Additionally, the effects of spring-back over blank holder force $(\mathrm{BHF})$, friction condition and forming rate were also analysed [24]. Researchers also examined parameters like punch, die radius, punch radius and punch holder by using genetic algorithms to reach the most suitable die design [25]. In the literature, there are also studies about springback amounts in cold bending processes as another type of bending process [26]. In flanging processes, springback values were estimated with different die radiuses and die drops [27, 28]. Moreover, in draw bending processes, the effects of die radius and waiting time of punch on the amounts of spring-back were also among the examined subjects [29]. Researchers have obtained spring-back values in free bending processes at different radius and 0 angles and compared them to each other by modelling a number of artificial neural networks [30]. Some researchers used coined bending techniques of springback and spring-go values. The coined bending technique is commonly applied in the process of $\mathrm{V}$-bending to eliminate spring-back and spring-go and achieve the required bending angle. These studies also illustrated the variations among spring-back and spring-go characteristics for different coined-bead widths and heights $[31,32]$.

Furthermore, a noteworthy study was carried out about investigating the effects of coining force on spring-back reduction in the process of $\mathrm{V}$-bending [33].
Additionally, fracture and cracking occurred when Hardox 500 sheet material was formed at $90 \mathrm{~V}$ bottoming bending into dies at room temperature. Hardox 500 sheet materials were normalized at different temperatures to increase formability [34].

In this study, V-bottoming bending processes were carried out by using 4-mm-thickX10CrAlSi24 (1.4762) sheet materials (they are widely used for bending processes in the energy sector) for $30^{\circ}, 60^{\circ}, 90^{\circ}$ bending angles and a $4.5-\mathrm{mm}$ punch tip radius. V-bottoming bending processes were carried out without leaving the punch on the material and allowing the punch to crush the sheet material sectional area. During bending of X10CrAlSi24 (1.4762) sheet materials, cracking and tearing occur due to their brittleness at room temperatures. To avoid this phenomenon, bending was carried out by applying normalization treatments at different temperatures.

\section{EXPERIMENTAL}

In the experiments, 4-mm-thick X10CrAlSi24 (1.4762) specimens were chosen and their chemical composition is given in Tab. 1. The specimens were prepared by hydraulic shearing in dimensions of $30 \times 60$ $\mathrm{mm}$, with a $0^{\circ}$ rolling direction. The burrs that occurred as a result of shearing were cleaned. The male punch and the female die (matrix) of the bending die used in the experimental study were made of C1390 shear steel and manufactured in a CNC Vertical Machining centre with precision. In bending die materials, cracking and fracturing may occur because of impact. For this reason, tempering was applied to avoid the internal stresses in the die material. Fig. 2 shows V-bottoming bending die and punches.

Table 1 Chemical composition of X10CrAISi24 material

\begin{tabular}{|c|c|c|c|c|c|c|c|}
\hline Material & $\mathrm{C}$ & $\mathrm{Si}$ & $\mathrm{Mn}$ & $\mathrm{P}$ & $\mathrm{S}$ & $\mathrm{Cr}$ & $\mathrm{Al}$ \\
\hline X10CrAlSi24 & 0,11 & 1,11 & 0,91 & 0,037 & 0,011 & 22,87 & 1,27 \\
\hline
\end{tabular}
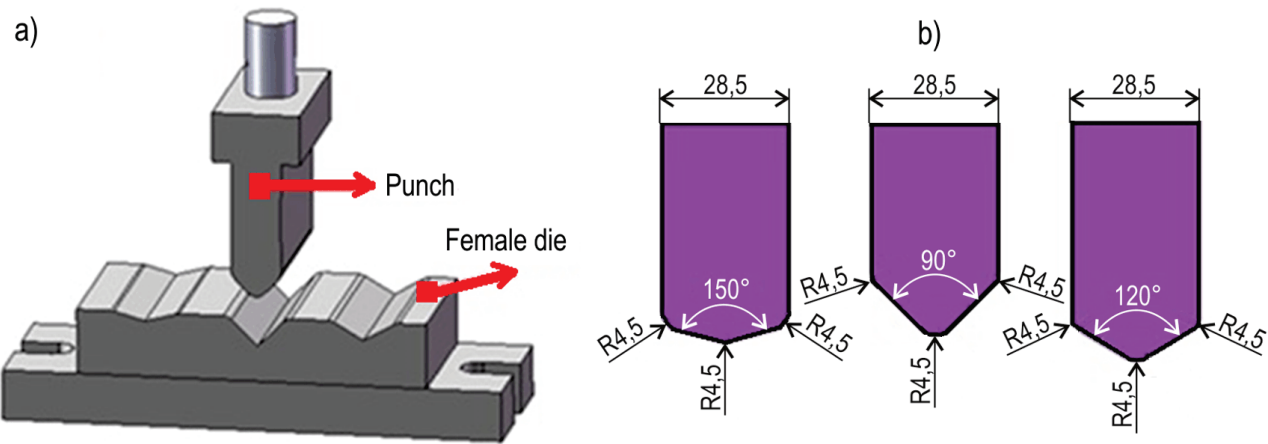

Figure 2 V-bottoming bending die and bending punches: a) Bending die, b) Bending punches

While a $30^{\circ} \mathrm{V}$-bottoming bending process was carried out on $\mathrm{X} 10 \mathrm{CrAlSi} 24$ sheet materials, $60^{\circ}$ and $90^{\circ}$ V-bottoming bending processes could not be applied. During the $60^{\circ}$ and $90^{\circ}$ bending processes, cracking and fracturing occurred on the sheet material (Fig. 3). To avoid this, normalization was applied at different temperatures $\left(800^{\circ}, 850^{\circ}, 900^{\circ}\right.$ and $\left.950{ }^{\circ} \mathrm{C}\right)$ to determine at which temperature interval micro cracking occurred. Besides, the bending processes were carried out on the heat-treated specimens $\left(30^{\circ}, 60^{\circ}\right.$ and $\left.90^{\circ}\right)$ without keeping the punch on the sheet material and by allowing the punch to crush the sheet material deformation area. After the bending process, the micro structures of non-heat-treated specimens (bent at room temperature) were compared at the end of normalisation heat treatment at $800^{\circ}, 850^{\circ}$, $900^{\circ}$ and $950^{\circ} \mathrm{C}$ and the temperatures at which the cracks occurred were determined. In the experiment series, normalization was applied to X10CrAlSi24 specimens of $30 \times 60 \mathrm{~mm}$ sizes at different temperatures. V-bottoming bending processes were carried out by leaving and not 
leaving space (equal to sheet thickness) between the punch and the die. Tests were conducted at free bending force and a $25-\mathrm{m} / \mathrm{min}$ punch drop speed. The parameters used in the bending processes are given in Tab. 2. In the study, different parameters were used and a total of 130 tests were made. For the purpose of reliability, each test was repeated 5 times. Spring-back and spring-go graphics were obtained by taking the arithmetic mean of the values. The results were also compared to each other.

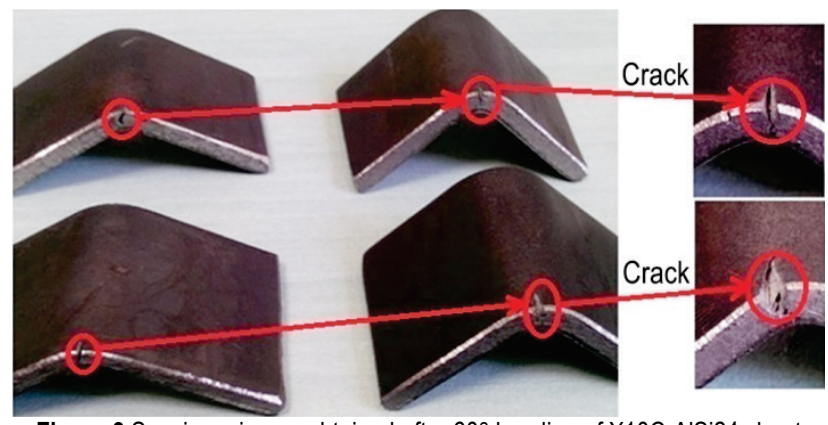

Figure 3 Specimen image obtained after $60^{\circ}$ bending of $\mathrm{X} 10 \mathrm{CrAISi} 24$ sheet material

Table 2 Bending parameters used in the experimental study

\begin{tabular}{|c|c|c|c|c|c|c|}
\hline \multirow{2}{*}{ Material } & $\begin{array}{c}\text { Bending } \\
\text { parameter }\end{array}$ & $\begin{array}{c}\text { Normalizing temperature } \\
T,{ }^{\circ} \mathrm{C}\end{array}$ & $\begin{array}{c}\text { Bending } \\
\text { process }\end{array}$ & $\begin{array}{c}\text { Sheet thickness } \\
S, \mathrm{~mm}\end{array}$ & $\begin{array}{c}\text { Bending angle } \\
\alpha,{ }^{\circ}\end{array}$ & $\begin{array}{c}\text { Number of } \\
\text { tests }\end{array}$ \\
\hline \multirow{2}{*}{ X10CrAlSi24 } & unheat-treated & at room temperatures & direct crushed & 4 & 30 & 10 \\
\cline { 2 - 7 } & heat-treated & $800-850-900-950$ & direct crushed & 4 & $30-60-90$ & 120 \\
\hline \multicolumn{7}{|c|}{ Total experiment number } \\
\hline
\end{tabular}

The specimens that were obtained in the V-bottoming bending processes were subjected to a pre-measurement process with an angle gauge and then each piece was measured accurately by using a CMM device. During measurement, 8 points were taken on the specimen and the angle values between these points were measured with precision (Fig. 4a). So, any potential measurement error was minimized, and the reliability of the results was increased. At the end of the V-bottoming bending process, material micro structure characterization was examined by cutting a piece from specimen deformation areas with the aid of a wire erosion machine for the purpose of observation of micro crack formations in the specimen interior structures depending on deformation (Fig. 4b). A Leica brand optical microscope was used for this purpose, and especially the material deformation in the bending area was evaluated.
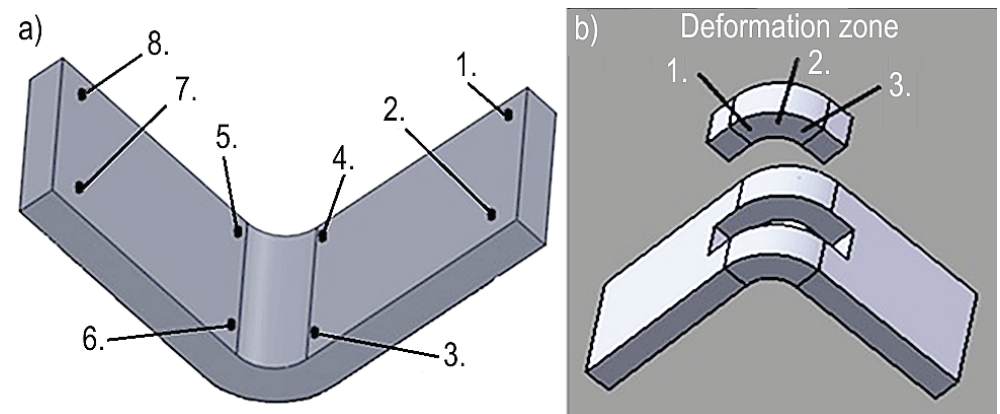

Figure 4 Points taken in CMM device and the area cut at wire erosion

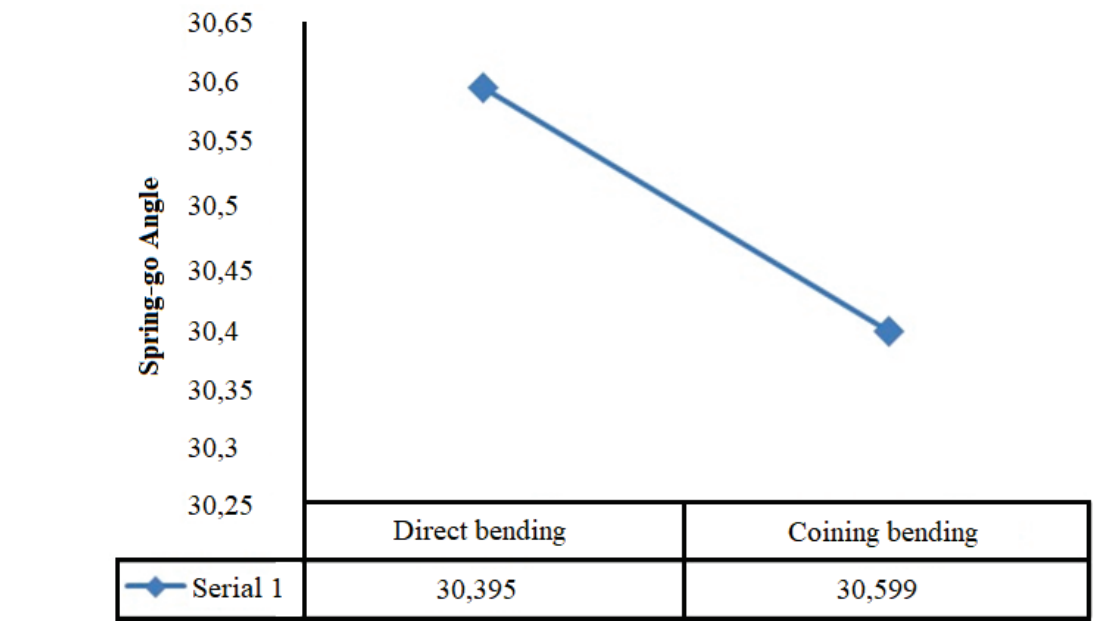

Figure $\mathbf{5}$ Spring-go values obtained in $30^{\circ}$ bending applications, arithmetical mean of these values and spring-go angle

In order to investigate the changes in the deformation zones before and after the bending process, sanding, polishing $(600,800,1000,1200$ grid) and etching process were applied. $5 \%$ Nital solution $\left(5 \mathrm{ml} \mathrm{HNO}_{3}, 95 \mathrm{ml} \mathrm{H}_{2} \mathrm{O}\right)$ was used as an etchant. Microstructure views were than obtained with the Leica optical microscope. 


\section{RESULTS AND DISCUSSION}

While the $30^{\circ}$ bending processes were carried out on the X10CrAlSi24 specimens, cracks and tearing were observed in the bending areas of the $60^{\circ}$ and $90^{\circ}$ bending processes. Normalization heat treatment was applied at different temperatures to improve the formability of the X10CrAlSi24 specimens.

As a result of the normalization treatment, no cracking or fracturing was observed on the specimens that were subjected to the bending processes. Spring values were measured on the specimens with precision by a coordinate measuring device (CMM) and spring-back and spring-go values were determined. The spring-go values of the X10CrAlSi2 4 sheet material obtained in the $30^{\circ}$ bending processes at room temperature and the arithmetical mean of these values are shown in Fig. 5. Fig. 5 shows that the spring-go amount of the processes carried out by the coined sheet material bending area with the punch was $66 \%$ lower in comparison to the processes in which the punch was directly taken away without waiting on the sheet material.The spring-go amount is obtained by subtracting the bending angle from the angle obtained at the end of the V-bottoming bending process. For example, the spring-go value was obtained as $0.599^{\circ}$ by subtracting the bending angle of punch $30^{\circ}$ from the spring-go value $30.599^{\circ}$ that was obtained as a result of the direct bending process. The ideal bending angle was obtained by adding the spring-go value to the punch bending angle. The micro structure image of the specimen taken from the central deformation area after the $30^{\circ} \mathrm{V}$ - bottoming bending processes at room temperature is shown in Fig. 6. From the micro structure image (Fig. 6), it was observed in the interior deformation area of the $30^{\circ}$ bending process specimen that crack formations occurred, and this could be significantly effective from the point of material forming and strength. As it is known, the $\mathrm{X} 10 \mathrm{CrAlSi} 24$ sheet material is hard and resistant to formability, and it consequently caused interior cracks during the bending process.

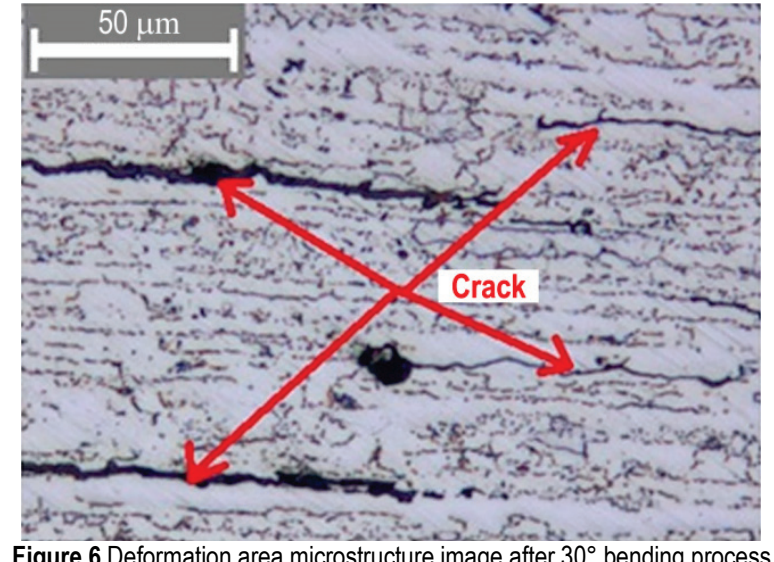

So, in the material shaping process, for the purpose of decreasing the stress areas (in the structure) of high density and increasing the material ductility by decreasing the hardness value, normalization annealing was carried out at $800^{\circ}, 850^{\circ}, 900^{\circ}$ and $950^{\circ} \mathrm{C}$.

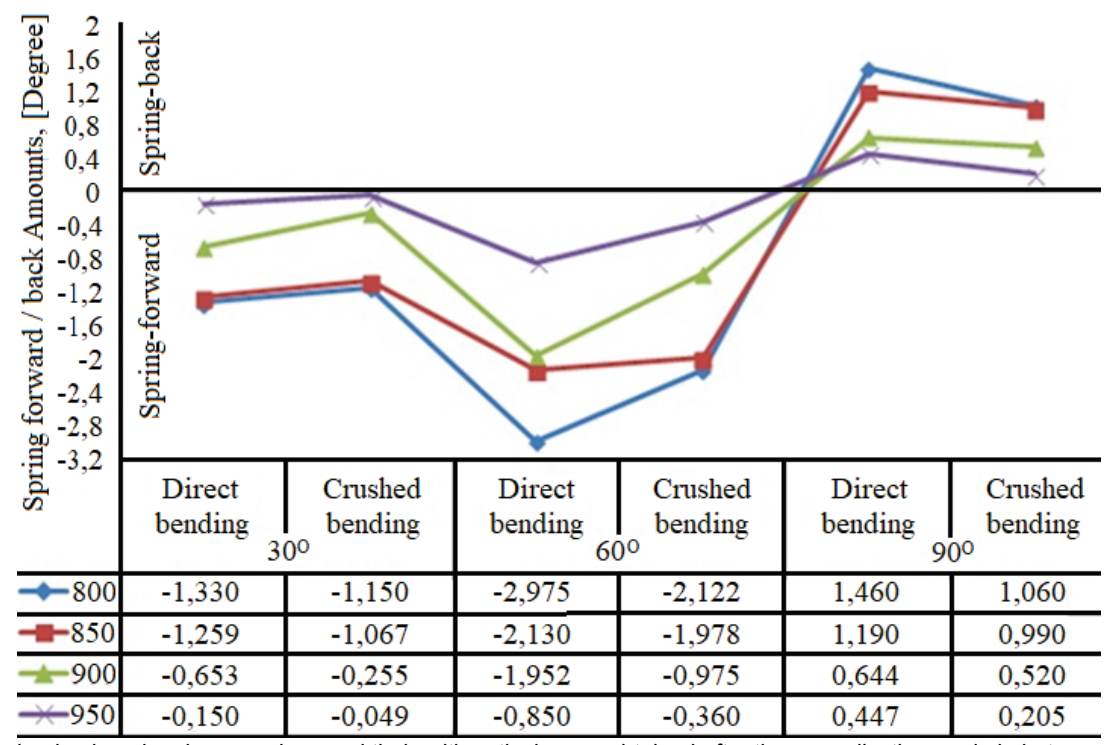

Figure 7 Spring-back and spring-go values and their arithmetical mean obtained after the normalization made in between $800^{\circ}-950^{\circ}$

After the heat treatment, V-bottoming bending processes were carried out on the materials. The arithmetic means of the spring-back and spring-go values after bending are given in Fig. 7. Direct and coined Vbottoming bending processes were carried out on the normalization annealed specimens (at $800^{\circ}, 850^{\circ}, 900^{\circ}$ and $950^{\circ} \mathrm{C}$ ) by using $30^{\circ}, 60^{\circ}$ and $90^{\circ}$ bend punches.

As a result of bending, in the direct and coined $30^{\circ}$ and $60^{\circ}$ bending applications at increasing normalization temperatures, the spring-go value decreased when the spring-back value decreased in the $90^{\circ}$ bending applications. After $30^{\circ}, 60^{\circ}$ and $90^{\circ}$ direct and coined bending tests, materials which were normalized at 800 , 850,900 and $950{ }^{\circ} \mathrm{C}$ were compared to each other at the same and different temperatures from the point of springgo and -back values. As a result, when the coined bending process at $800{ }^{\circ} \mathrm{C}$ was compared to direct bending, it was determined that it decreased the spring-go amount by $13.53 \%$ and $28.67 \%$ in the $30^{\circ}$ and $60^{\circ}$ bending processes respectively, and it decreased the spring-back value by $30.41 \%$ in $90^{\circ}$ bending. When the coined bending process at $850^{\circ} \mathrm{C}$ was compared to direct 
bending, it was observed that it decreased the spring-go value by $15.25 \%$ in $30^{\circ}$ bending and by $7.14 \%$ in $60^{\circ}$ bending, whereas it decreased the spring-back value by $16.80 \%$ in the $90^{\circ}$ bending process.

When the direct and coined V-bottoming bending applications of $30^{\circ}$ at $950{ }^{\circ} \mathrm{C}$ were compared to those at
$900{ }^{\circ} \mathrm{C}$, it was seen that the heat treatments decreased the spring-go values by $77 \%$ and $80.78 \%$ and again decreased the spring-go values by $56.45 \%$ and $63.07 \%$ in the $60^{\circ}$ applications respectively. It was observed that the springback value was decreased by $30.60 \%$ in the direct bending processes, whereas $60.57 \%$ in coined bending.
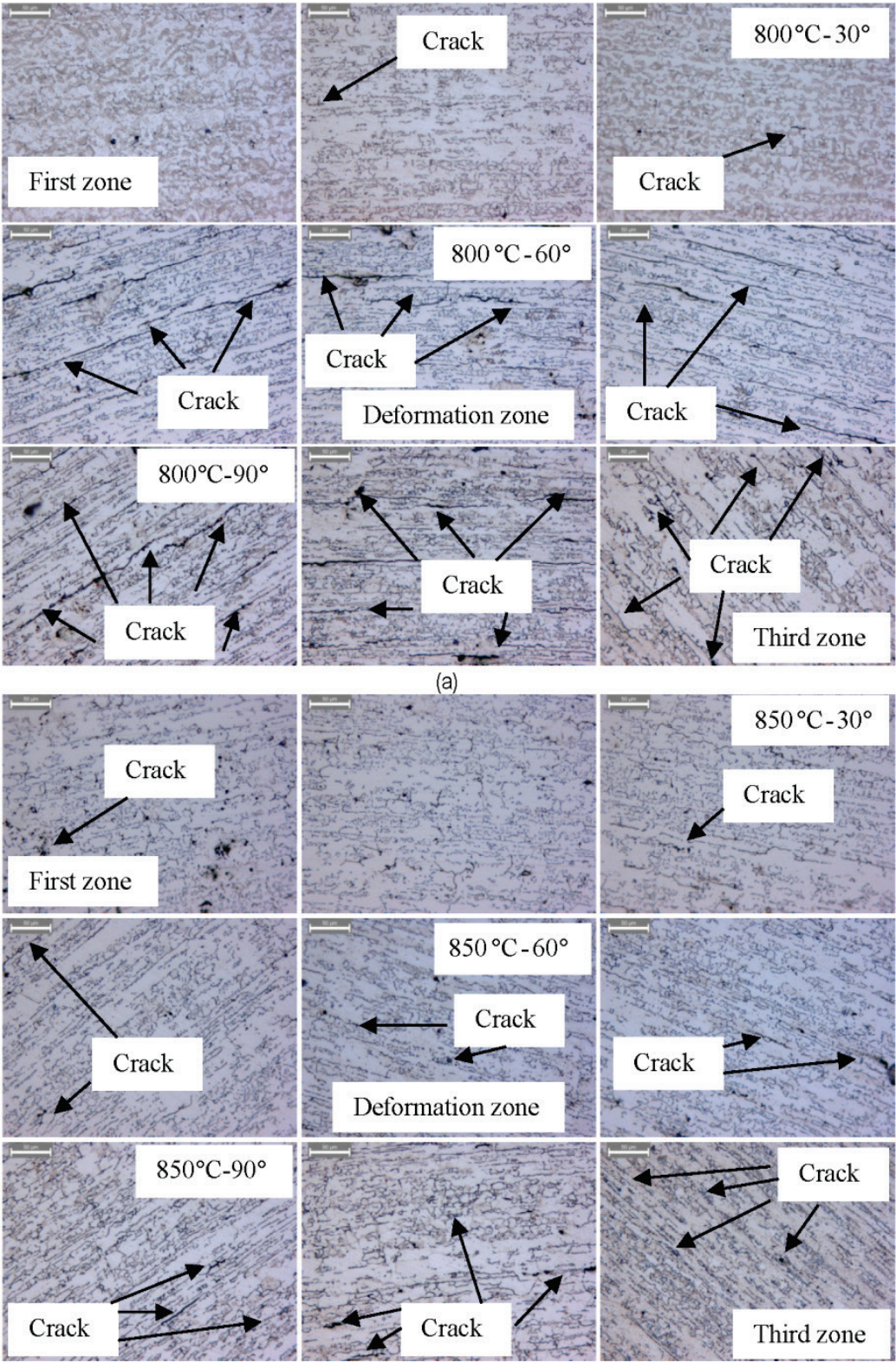

(b)

Figure 8 Microstructure images of the normalization annealed specimens during $30^{\circ}, 60^{\circ}$ and $90^{\circ}$ bending process; (a) $800^{\circ} \mathrm{C}$, (b) $850^{\circ} \mathrm{C}$

The spring-go amount is obtained by subtracting the bending angle from the angle obtained in the V-bottoming bending process. For example, after normalization at $900^{\circ}$, the spring-go value of $0.653^{\circ}$ (taken from Fig. 7) that was obtained during $30^{\circ}$ direct bending of the material is added to the $150^{\circ}$ bending angle (bending angle of the punch), and the ideal bending angle is obtained. From here, the angle calculation which is to be adjusted in the male punch is as follows:

Angle which is to be adjusted in male punch $=$ Angle of bent + spring-go: $\alpha=150^{\circ}+0.653^{\circ}=150,653^{\circ}$.

The spring-back value is calculated by subtracting the obtained angle from the bending angle. For example, after normalization at $950^{\circ} \mathrm{C}$ in the $90^{\circ}$ direct bending of the material, the obtained spring-back value $0.447^{\circ}$ (From Fig. 7) is subtracted from the $90^{\circ}$ bending angle (bending angle of punch). This way, the suitable bending angle is obtained. From here, the angle calculation which is to be adjusted in the male punch is as follows:

Angle which is to be adjusted in the male punch $=$ Angle of bent + spring-back: $\alpha=90^{\circ}-0.447^{\circ}=89,553^{\circ}$.

So, when punches are manufactured, bending at the desired angle is realized by the addition or subtraction of spring-go or-back to the desired angle. The designer makes the suitable die design with respect to the value calculation of which is described above.

After normalization treatment at $800^{\circ}, 850^{\circ}, 900^{\circ}$ and $950{ }^{\circ} \mathrm{C}$, the bending processes were carried out with $30^{\circ}$, 
$60^{\circ}$ and $90^{\circ}$ punches. The microstructure images of the specimens that were normalized at $800{ }^{\circ} \mathrm{C}$ and $850{ }^{\circ} \mathrm{C}$ are given in Fig. 8. When the microstructure images were examined from the point of the specimen areas that are shown in Fig. $4 \mathrm{a}$ and $4 \mathrm{~b}$, it was observed that increased bending angle in the $30^{\circ}, 60^{\circ}$ and $90^{\circ}$ bending processes and capillary cracks also increased in the deformation areas. After the bending of specimens that were normalized at $900^{\circ}$ and $950{ }^{\circ} \mathrm{C}$, the micro structure images of the specimen areas indicated in Fig. $4 \mathrm{~b}$ are given in Fig. 9.
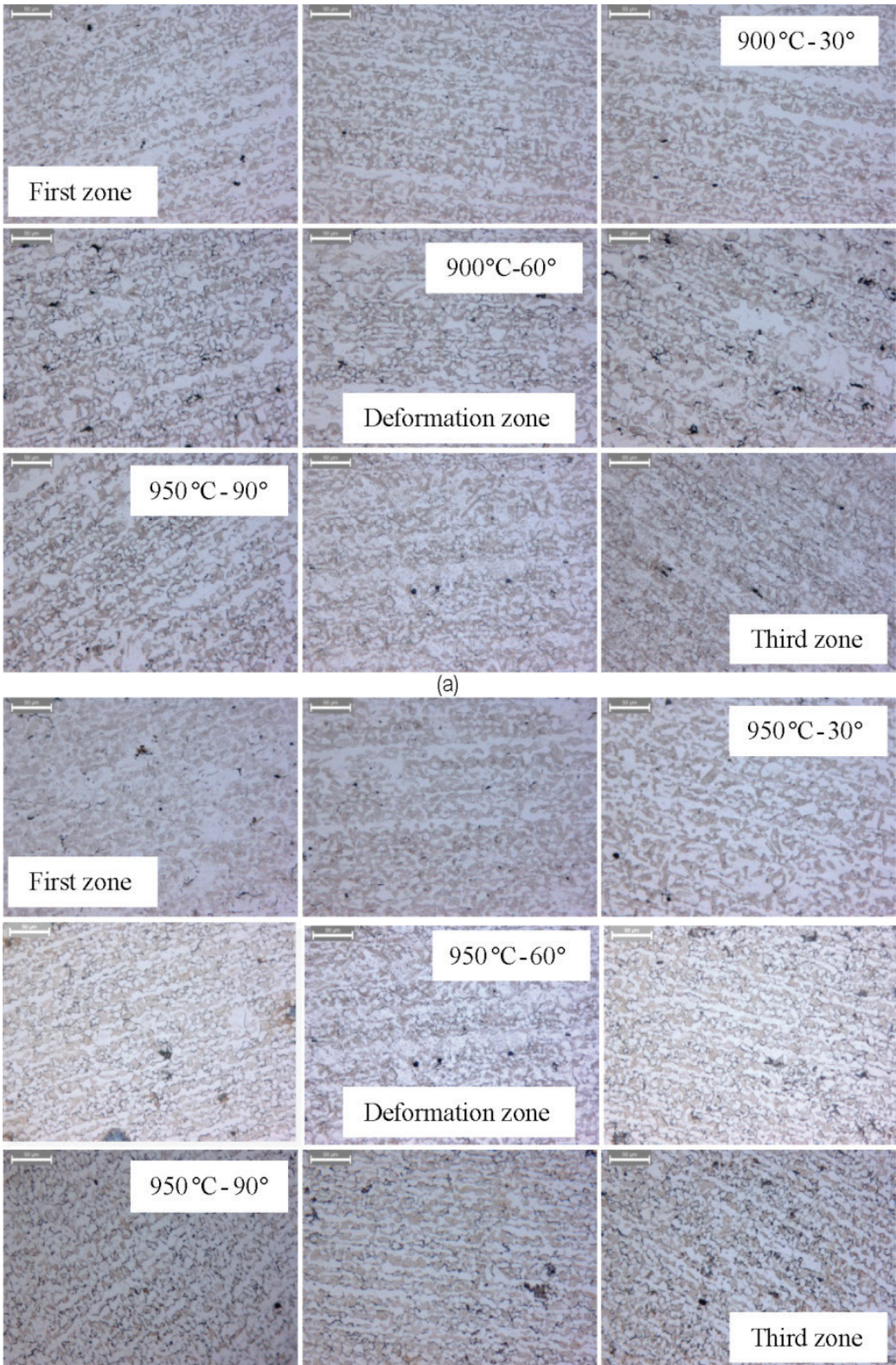

(b)

Figure 9 Micro structure images of normalization annealed specimens obtained in $30^{\circ}, 60^{\circ}$ and $90^{\circ}$ bending process; (a) $900^{\circ} \mathrm{C}$, (b) $950{ }^{\circ} \mathrm{C}$

In the micro structure images and especially in the deformation areas, no capillary crack formation was observed. This behaviour was minimized by the effect of the temperature increase in the material deformation area. It is seen from the micro structure images that the similar effect triggers capillary crack formation at low temperatures as a negative effect in terms of material strength. When an evaluation is made from the point of heat-treated specimens both at room temperature and low temperatures, it is reported that this situation which is created by material shaping studies and deformation is due to internal stresses and consequently based on capillary crack formation. When Fig. 10 is examined, it is seen that the polynomial curve equations that were obtained with the data from the experimental study were in harmony with each other. As a result of the R2 values approaching 1 in the obtained polynomial curve equations, it is concluded that the relationship between experimental data and polynomial curve equations was significant. 

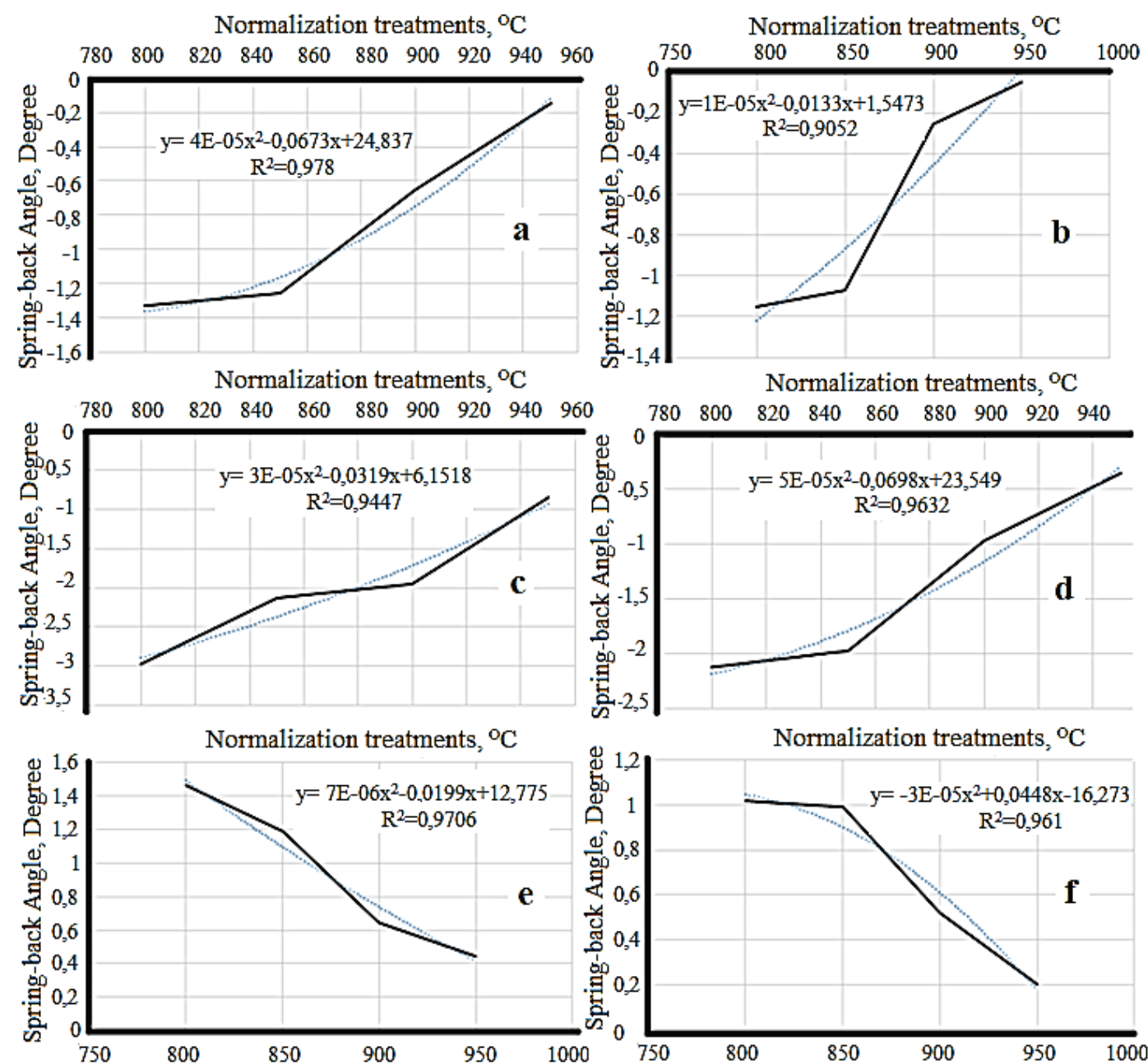

Figure 10 Spring-back and forward stretching quantities and obtained polynomial curve equations; (a) $30^{\circ}$ direct bending, (b) $30^{\circ}$ crushed bending, (c) $60^{\circ}$ direct bending, (d) $60^{\circ}$ crushed bending, (e) $90^{\circ}$ direct bending, (f) $90^{\circ}$ crushed bending

\section{CONCLUSIONS}

The test results that were obtained by bending 4-mmthick X10CrAlSi24 specimens with a punch (R-6 mm) at $30^{\circ}, 60^{\circ}$ and $90^{\circ}$ degrees are given below.

While spring-back occurred at $90^{\circ}$ bending, spring-go took place at $30^{\circ}$ and $60^{\circ}$ bending applications. In the $30^{\circ}$ and $60^{\circ}$ bending processes, while the coined bending processes decreased the spring-go amount with respect to direct bending processes, it decreased the spring-back values at $90^{\circ}$. In the $30^{\circ}$ bending processes at room temperature, it was seen that coined bending decreased the spring-go value approximately by $66 \%$ with respect to direct bending. After bending the specimen at $30^{\circ}$, no crack was observed in the macro scale and capillary cracks were seen in the micro structural examination. In the $60^{\circ}$ and $90^{\circ}$ bending applications, large scale cracks and tearing occurred in the specimens. As a result of the normalization treatment at $800{ }^{\circ} \mathrm{C}$ and $850{ }^{\circ} \mathrm{C}$, with the increased bending angle, the capillary cracks in the internal structure of the specimen increased. In the normalization treatments at $900{ }^{\circ} \mathrm{C}$ and $950{ }^{\circ} \mathrm{C}$, no crack was observed.

When the $30^{\circ}$ direct and coined bending processes at $950{ }^{\circ} \mathrm{C}$ were compared to those at $800{ }^{\circ} \mathrm{C}$, it was seen that direct and coined bending at $950{ }^{\circ} \mathrm{C}$ decreased the springgo values by $88.72 \%$ and $95.73 \%$ respectively, while in the $60^{\circ}$ bending practices, it decreased these values by
$71.42 \%$ and $83.03 \%$ respectively. When the comparison was made for $90^{\circ}$, it was observed that the decrease in the spring-back value was $69.38 \%$ in direct bending and $79.82 \%$ in coined bending.

\section{REFERENCES}

[1] Thipprakmas, S. \& Rojananan, S. (2008). Investigation of spring-go phenomenon using finite element method. Material and Design, 29(8), 1526-1532. https://doi.org/10.1016/..matdes.2008.02.002

[2] Ozdemir, M., Gökmeşe, H., Dilipak, H., \& Yılmaz, V. (2014). Investigation as experimental and micro-structural of the effect to spring back/forward amount of $16 \mathrm{Mo} 3$ (1.5415) sheet materials of different heat-treatments. ISITES, E-Publishing, Inc. Karabük, Turkey, 148-155.

[3] Imai, K., Koyama, J., \& Jin, Y. (2008). High-accuracy Vbending system by real time identifying material property. Journal of Materials Processing Technology, 201(1-3), 193-197. https://doi.org/10.1016/j.jmatprotec.2007.11.132

[4] Tekaslan, Ö., Şeker, U., \& Özdemir, A. (2006). Determining spring back amount of steel sheet metal has $0.5 \mathrm{~mm}$ thickness in bending dies. Material and Design, 27(3), 251-258. https://doi.org/10.1016/j.matdes.2004.10.006

[5] Tekaslan, O., Şeker, U., \& Gerger, N. (2008). Determination of Copper sheet metal in $\mathrm{V}$ bending dies. Journal of the Faculty of Engineering and Architecture of Gazi University, 23(1), 201-38. https://www.researchgate.net/publication/285441389

[6] Tekaslan, Ö., Gerger, N., \& Şeker, U. (2008). 
Determination of spring-back of stainless steel sheet metal in $\mathrm{V}$ bending dies. Material and Design, 29(5), 1043-1050. https://doi.org/10.1016/j.matdes.2007.04.004

[7] Tekiner, Z. (2004). An experimental study of the examination of spring-back of sheet metals with several thicknesses and properties in bending dies. Journal of Materials Processing Technology, 145(1), 109-117. https://doi.org/10.1016/j.jmatprotec.2003.07.005

[8] Ozturk, F., Toros, S., \& Kilic, S. (2009). Tensile and spring-back Behavior of DP600 advanced high strength steel at warm temperatures. Journal of Iron and Steel Research, International, 16(6), 41-46. https://doi.org/10.1016/S1006-706X(10)60025-8

[9] Choi, S. H. \& Chin, K. G. (2006). Prediction of spring-back behavior in high strength low carbon steel sheets. Journal of Materials Processing Technology, 171(3), 385-392. https://doi.org/10.1016/j.jmatprotec.2005.07.012

[10] Schwarze, M., Vladimirov, I. N., \& Reese, S. (2011). Sheet metal forming and spring back simulation by means of a new reduced integration solid-shell finite element technology. Computer Methods in Applied Mechanics and Engineering, 200(5-8), 454-476. https://doi.org/10.1016/j.cma.2010.07.020

[11] Asgari, S. A., Pereira, M., Rolfe, B. F., Dingle, M., \& Hodgson, P. D. (2008). Statistical analysis of finite element modeling in sheet metal forming and spring back analysis, Journal of Materials Processing Technology, 203(1-3), 129 136. https://doi.org/10.1016/j.jmatprotec.2007.09.073

[12] Chen, F. K. \& Ko, S. F. (2011). Deformation Analysis of Spring-back in L-bending of Sheet Metal, Advanced Science Letters, 4(6-7), 1928-1932. https://doi.org/10.1166/asl.2011.1713

[13] Fei, D. \& Hodgson, P. (2006). Experimental and numerical studies of spring back in air V-bending process for cold rolled TRIP steels, Nuclear Engineering and Design, 236(18), 1847-1851. https://doi.org/10.1016/j.nucengdes.2006.01.016

[14] Chen, P., Koc, M., \&Wenner, M.L. (2008). Experimental investigation of spring back variation in forming of high strength steels. Journal of Manufacturing Science and Engineering, 130(4), 1-9. https://doi.org/10.1115/1.2951941

[15] Dilipak, H., Ozdemir, M., \& Sarkaya, M. (2013). Effects of Material Properties and Punch Tip Radius on SpringForward in $90^{\circ} \mathrm{V}$ Bending Processes, Journal of Iron and Steel Research, International, 20(10), 64-69. https://doi.org/10.1016/S1006-706X(13)60178-8

[16] Özdemir, M., Gökmeşe, H., Yılmaz, V., \& Dilipak, H. (2015). Characterization of Microstructure and Bending Response of Sheet Material: Influence of Thickness. Journal of Advanced Materials and Processing, 3(1), 3-14. http://jmatpro.iaun.ac.ir/article_8709_1b91ca3e8e49f585af8d1c76 6fd05d61.pdf

[17] Panthi, S. K., Ramakrishnan, N. M., Ahmed, S. S., \& Goel, M. D. (2010). Finite Element Analysis of sheet metal bending process to predict the spring back. Material and Design, 31(2), 657-662. https://doi.org/10.1016/j.matdes.2009.08.022

[18] Thipprakmas, S. \& Phanitwong, W. (2011). Process parameter design of spring-back and spring-go in Vbending process using Taguchi technique. Material and Design, 32(8-9), 4430-4436. https://doi.org/10.1016/j.matdes.2011.03.069

[19] Grizelj, B., Cumin, J., \& Grizelj, D. (2010). Effect of spring-back and spring-forward in V-die bending of St1403 sheet metal plates. Journal for Theory and Application in Mechanical Engineering, 52(1), 181-186.

[20] Osman, M. A., Shazly, M., Mokaddem, A. E., \& Wifi, A. S. (2010). Spring back prediction in V-die bending: modelling and experimentation. Journal of Achievements in Materials and Manufacturing Engineering, 38(2), 179-186. https://www.researchgate.net/publication/283270256

[21] Toros, S., Polat, A., \& Öztürk, F. (2012). Formability and springback characterization of TRIP800 advanced high strength steel. Material and Design, 41, 298-305. https://doi.org/10.1016/j.matdes.2012.05.006

[22] Bakhshi, J., Rahmani, B., Daeezade, V., \& Gorji, A. (2009). The study of spring-back of CK67 steel sheet in Vdie and U-die bending processes. Material and Design, 30, 2410-2419. https://doi.org/10.1016/j.matdes.2008.10.018

[23] Ragai, L., Lazim, D., \& Nemes, A. (2005). Anisotropy and spring-back in draw-bending of stainless steel 410: experimental and numerical study. Journal of Materials Processing Technology, 166(1), 116-127. https://doi.org/10.1016/j.jmatprotec.2004.08.007

[24] Kim, H. S. \& Koç, M. (2008). Numerical investigations on spring back characteristics of aluminum sheet metal alloys in warm forming conditions. Journal of Materials Processing Technology, 204(1-3), 370-383. https://doi.org/10.1016/j.jmatprotec.2007.11.059

[25] Sousa, L., Castro, C., \& Antonio, C. (2006). Optimal design of $\mathrm{V}$ and $\mathrm{U}$ bending processes using genetic algorithms. Journal of Materials Processing Technology, 172(1), 35-41. https://doi.org/10.1016/j.jmatprotec.2005.08.011

[26] Zhu, Y. X., Liu, Y. L., Yang, H., \& Li, H. P. (2012). Development and application of the material constitutive model in springback prediction of cold-bending, Material and Design, 42, 245-258. https://doi.org/10.1016/j.matdes.2012.05.043

[27] Mkaddem, A. \& Saidane, D. (2007). Experimental approach and RSM procedure on the examination of spring back in wiping-die bending processes. Journal of Materials Processing Technology, 189(1-3), 325-333. https://doi.org/10.1016/j.jmatprotec.2007.02.004

[28] Song, N., Dong, Q., Jian, C., Wing, K. L., \& Shaofan, L. (2006). Effective models for prediction of spring back in flanging. Journal of Engineering Materials and Technology, 123(4), 456-461. https://doi.org/10.1115/1.1395019

[29] Ouakdi, E. H., Louahdi, R., Khirani, D., \& Tabourot, L. (2012). Evaluation of spring back under the effect of holding force and die radius in a stretch bending test. Material and Design, 35, 106-112. https://doi.org/10.1016/j.matdes.2011.09.003

[30] Garcia-Romeu, M. L., Ciurana, J., \& Ferrer, I. (2007). Spring back determination of sheet metals in an air bending process based on an experimental work. Journal of Materials Processing Technology, 191(1-3), 174-177. https://doi.org/10.1016/j.jmatprotec.2007.03.019

[31] Phanitwong, W. \& Thipprakmas, S. (2014).Determination of Coined-Bead Geometry in the V-Bending Process. Advances in Mechanical Engineering, 6, 345152. http://dx.doi.org/10.1155/2014/345152

[32] Thipprakmas, S. (2011). Finite Element Analysis on the Coined-Bead Mechanism during the V Bending Process. Material and Design, 32(10), 4909-4917. https://doi.org/10.1016/j.matdes.2011.05.054

[33] Leu, D. K. \& Hsieh, C. M. (2008). The Influence of Coining Force on Spring-Back Reduction in V-Die Bending Process. Journal of Materials Processing Technology, 196(1-3), 230-235. https://doi.org/10.1016/j.jmatprotec.2007.05.033

[34] Gökmeşe, H. \& Özdemir, M. (2016). The Effect of Heat Treatment on the Formability Behavior of Hardox-500 Sheet Material. $G U$ J SciPart: $C$, 4(4), 343-349. http://gujscgaziedutr/issue/24436 


\section{Contact information:}

Mustafa ÖZDEMiR, Asst. Prof. Dr.

Bozok University, Vocational School of Technical Sciences

Department of Machine and Metal Technology, Yozgat, Turkey

E-mail: mustafa.ozdemir@bozok.edu.tr

Hakan GÖKMEŞE, Asst. Prof. Dr.

Konya Necmettin Erbakan University

Seydişehir Ahmet Cengiz Engineering Faculty,

Dept. of Metal. and Material Eng.

42370, Seydişehir/Konya, Turkey

E-mail: hgokmese@konya.edu.tr 